\title{
Nutrient Content of the Plantain (Musa, AAB Group) During Growth and Fruit Production ${ }^{1}$
}

\author{
G. Samuels, A. Beale, and S. Torres ${ }^{2}$
}

\begin{abstract}
Plantains, cultivar Maricongo, were grown on a Humatas clay (Typic Tropohumults) in the humid mountains of Puerto Rico. Plants fertilized with $678 \mathrm{~kg} / \mathrm{ha}$ of a $10-5-20\left(\mathrm{~N}-\mathrm{P}_{2} \mathrm{O}_{5}-\mathrm{K}_{2} \mathrm{O}\right)$ fertilizer were sampled monthly from planting to harvest. There was only a small production of dry matter in the first 5 months of growth. Thereafter, growth progressed rapidly giving large increases in dry weight and plant height. Dry matter of the whole plant fluctuated from 5 to $6 \%$ for the first 10 months and then increased, peaking at $9 \%$ at 13 months, when harvested. The fruit averaged $32.6 \%$ dry matter. Leaves had a higher percentage of dry weight than pseudostem until 6 months of age. From 7 to 10 months, weights were similar. Thereafter, pseudostem weights were greater. Dry weight percentage of leaves was about three times that of pseudostems.

The percentages of $N$ and $P$ were higher in the leaf than in the pseudostem at all stages of growth; the reverse was true for K. The NPK levels tended to decrease with increasing age of the plant. The leaves had a higher nutrient uptake rate than the pseudostems in the early stages of growth for $\mathrm{N}$ and $\mathrm{P}$, but not for K. Ca and $\mathrm{Mg}$ levels indicated no clear difference between leaves and pseudostems. There was a trend for reduction in $\mathrm{Mg}$ content of the leaves with increasing age, and both leaves and pseudostems showed a definite drop in $\mathrm{Mg}$ level at the fruiting stage. The ratios of leaves to pseudostems for nutrient uptake at harvest were $\mathrm{N}, 1: 1 ; \mathrm{P}, 1: 1 ; \mathrm{K}, 1: 4 ; \mathrm{Ca}$, $1: 2 ;$ and $\mathrm{Mg}, 1: 2$.

Based on 2,988 plants/ha, a crop of plantains removes $70 \mathrm{~kg}$ of N, 9 of $\mathrm{P}$, 242 of $\mathrm{K}, 2$ of $\mathrm{Ca}$, and 11 of $\mathrm{Mg}$. In turn, left behind in the fields in pseudostems and leaves, were $262 \mathrm{~kg}$ of $\mathrm{N}, 13$ of $\mathrm{P}, 1,471$ of $\mathrm{K}, 208$ of $\mathrm{Ca}$, and 45 of $\mathrm{Mg}$, which were returned to the soil.
\end{abstract}

\section{INTRODUCTION}

Plantains provide an important source of starch in the Puerto Rican diet. The crop is grown intensively on plantation scale and has become one of the leading crops in Puerto Rico, being second only to sugarcane in economic value in 1974-75.

Much of the published research work in Puerto Rico on plantains has been conducted with attention to plant density (1), mineral nutrition requirements (2), and processing characteristics (4). No local investigations have been done with regard to the nutrient composition of the plant in relation to growth and fruit production.

Walmsley, in Trinidad, studied the mineral nutrition of two plantain cultivars (6) with the objective of developing rational NPK fertilizer requirements of the plant. Although such an approximation from total

' Manuscript submitted to Editorial Board July 11, 1977.

${ }^{2}$ Agronomist and Research Assistant, respectively, Agronomy and Soils Department, and Research Aid, Corozal Substation, Agricultural Experiment Station, University of Puerto Rico, Mayagüez Campus, Río Piedras, P. R. 
plant analysis can prove misleading ( $3, \mathrm{pp} 7-8)$, it does give the grower an idea of the relative importance and quantities of nutrients that a plantain crop accumulates, either from the soil or from fertilizers.

The purpose of this paper is to present the nutrient composition ( $N$, $\mathrm{P}, \mathrm{K}, \mathrm{Ca}, \mathrm{Mg}$ ) of the plantain during its growth and fruit production in the humid mountain region of Puerto Rico.

\section{MATERIALS AND METHODS}

Maricongo, a horn-type cultivar of the plantain subgroup of the Musa, AAB Group (5), was used in this study. The plants were grown on a Humatas clay (Typic Tropohumults) at the Corozal Substation, located in the humid mountain area of Puerto Rico. The soil chemical characteristics were as follows: $\mathrm{pH} 6.5$ (field limed, unlimed $\mathrm{pH} 4.8$ ), organic matter $3.24 \%$, cation exchange capacity $14.28 \mathrm{meq} / 100 \mathrm{~g}$ soil, available P $10 \mathrm{p} / \mathrm{m}$, and exchangeable cations in p/m: K-115, Ca-965, and Mg-100.

Corms preselected from plants with production of 40 or more plantains per bunch from neighboring farms were used as planting material The corms were peeled to discard necrotic tissue, immersed in a solution of Nemagon $70 \mathrm{EC}^{3}(1,064 \mathrm{ml} / 379 \mathrm{I}$ of water) for $5 \mathrm{~min}$ and planted $24 \mathrm{~h}$ later. At planting, a granular nematicide-insecticide, Dasanit, was applied at a rate of $56 \mathrm{~g}$ per planting hole, mixing the material with the soil and covering the corm. An additional $56 \mathrm{~g}$ was added every $6 \mathrm{mo}$ on the soil surface in a $0.75 \mathrm{~m}$ radius around the plant. Fertilizer (10-5-20) was applied at 1, 3, and 9 mo after planting, at the rate of $227 \mathrm{~g} /$ plant/application, equivalent to 204, 102, and 408 $\mathrm{kg} / \mathrm{ha}$ /year of $\mathrm{N}, \mathrm{P}_{2} \mathrm{O}_{5}$, and $\mathrm{K}_{2} \mathrm{O}$, respectively.

The experimental plot consisted of a double row of plants, $1.83 \mathrm{~m}$ between plants and between rows, with rows $110 \mathrm{~m}$ long. The $1.83 \times$ $1.83 \mathrm{~m}$ distance corresponds to 2,988 plants/ha. Three plants were taken once a month from June 1, 1973 to July 15, 1974 to determine green and dry weights and for chemical analysis. The plant was divided into roots, corm, pseudostem, and leaves. Root and corm data are not presented (except for the initial corm at planting) for economy of space. Flowering occurred in April 1974 in the 10th mo and fruit was harvested 93 days later.

The plant material was oven dried at $70^{\circ} \mathrm{C}$, ground, and chemically analyzed using a wet-ash digestion method of sulfuric acid and hydrogen peroxide (3). Because of high $\mathrm{K}$ values in certain tissues, results were

\footnotetext{
${ }^{3}$ Trade names are used in this publication solely for the purpose of providing specific information. Mention of a trade names does not constitute a guarantee or warranty of materials by the Agricultural Experiment Station of the University of Puerto Rico or an endorsement over other equipment or materials not mentioned.
} 
checked against a nitric-sulfuric-perchloric acid digestion. Investigations are underway to determine which method of digestion reflects most accurately the $\mathrm{K}$ status of plantain tissue. In this report, the data reported are from the sulfuric acid-hydrogen peroxide digestion.

\section{RESULTS AND DISCUSSION}

\section{DRY MATTER PRODUCTION}

Production of dry matter was small during the first 5 mo of growth (table 1). This covered the period from germination to small-plant stage with about six broad leaves. After the sixth month, growth progressed rapidly giving large increases in dry weight (table 1).

TABLE 1. - Percentage dry matter and weight of components of a plantain plant at various stages of growth

\begin{tabular}{crrrrrr}
\hline \multirow{2}{*}{$\begin{array}{c}\text { Age of } \\
\text { plant }\end{array}$} & \multicolumn{2}{c}{ Leaves $^{1}$} & \multicolumn{2}{c}{ Pseudostem $^{2}$} & \multicolumn{2}{c}{ Whole plant } \\
\cline { 2 - 7 } & Dry matter & Weight & Dry matter & Weight & Dry matter & Weight \\
\hline Mo & $\%$ & $g$ & $\%$ & $g$ & $\%$ & $g$ \\
0 (corm) & - & - & - & - & 6.34 & 72 \\
1 & 9.14 & 7 & 3.88 & 6 & 5.51 & 13 \\
2 & 8.63 & 15 & 5.31 & 12 & 6.83 & 27 \\
3 & 9.00 & 49 & 3.52 & 37 & 5.41 & 86 \\
4 & 9.79 & 203 & 3.13 & 103 & 5.71 & 306 \\
5 & 13.24 & 274 & 3.74 & 154 & 6.92 & 428 \\
6 & 19.23 & 1,022 & 3.90 & 544 & 8.14 & 1,566 \\
7 & 13.12 & 953 & 4.32 & 972 & 6.44 & 1,925 \\
8 & 15.20 & 1,435 & 4.00 & 1,233 & 6.63 & 2,668 \\
9 & 16.20 & 1,728 & 4.20 & 1,728 & 6.64 & 3,482 \\
10 & 15.80 & 1,829 & 4.10 & 1,852 & 6.49 & 3,681 \\
11 & 17.00 & 2,084 & 5.20 & 2,644 & 7.49 & 4,728 \\
12 & 18.10 & 2,276 & 6.40 & 3,385 & 8.65 & 5,661 \\
13 & 20.30 & 2,092 & 8.90 & 3,980 & 14.67 & $9,713^{3}$ \\
\hline
\end{tabular}

${ }^{1}$ Leaves include lamina, midribs, and petioles.

${ }^{2}$ Pseudostem includes infloresence and external stalk after ninth month.

${ }^{3}$ Including fruit weight of 3,641 ( $(32.6 \%$ D.M.).

There was from 5 to $6 \%$ fluctuation of dry matter of the whole plant for the first $10 \mathrm{mo}$, with the exception of an unexplainable value of $8.14 \%$ at 6 mo. Beginning at $11 \mathrm{mo}$, the percentage dry matter increased, peaking at 13 mo when the fruit was harvested. The fruit averaged $32.6 \%$ dry matter.

Distribution of dry weight within the plant showed that leaves (lamina, midribs, and petioles) produced more than did pseudostems up until 6 mo (table 1). From 7 to 10 mo, dry weights were similar. Thereafter, pseudostem weights were higher. Leaves were about three times the percentage of dry matter of pseudostems. Both plant parts had increases in percentage of dry matter with increasing age (table 1). 
The nutrient ( $\mathrm{N}, \mathrm{P}, \mathrm{K}, \mathrm{Ca}, \mathrm{Mg}$ ) contents, in percentage and actual dry weights of the plantain at various ages of growth, are given in tables 2 to 6 .

Percentages of $\mathrm{N}$ and $\mathrm{P}$ were higher in the leaves than in the pseudostem for 11 stages of growth (tables 2 and 3). The reverse was true for K (table 4). The NPK levels tended to decrease with increasing age of the plant. Both leaves and pseudostems showed a drop in NPK percentages at the fruiting stage (12 to $13 \mathrm{mo}$ ). This decrease was

TABLE 2.-Dry-weight $N$ content (percentage and weight) of components of a plantain plant at various stages of growth

\begin{tabular}{ccccccc}
\hline \multirow{2}{*}{$\begin{array}{c}\text { Age of } \\
\text { plant }\end{array}$} & \multicolumn{6}{c}{ N Content } \\
\cline { 2 - 7 } & Leaves & Pseudostem & Whole plant & Leaves & Pseudostem & Whole plant \\
\hline Mo & $\%$ & $\%$ & $\%$ & $g$ & $g$ & $g$ \\
0 (corm) & - & - & 1.64 & - & - & 1.2 \\
1 & 3.23 & 2.50 & 2.92 & 0.2 & 0.1 & .3 \\
2 & 2.94 & 1.67 & 2.33 & .4 & .2 & .6 \\
3 & 3.47 & 2.25 & 2.94 & 1.7 & .9 & 2.6 \\
4 & 3.54 & 2.31 & 3.12 & 7.2 & 2.4 & 9.6 \\
5 & 3.71 & 2.33 & 3.22 & 10.2 & 3.6 & 13.8 \\
6 & 3.15 & 1.80 & 2.68 & 32.2 & 9.8 & 42.0 \\
7 & 3.40 & 1.90 & 2.65 & 32.4 & 18.5 & 50.9 \\
8 & 3.42 & 1.83 & 2.69 & 49.1 & 22.6 & 71.7 \\
9 & 3.06 & 1.74 & 2.39 & 52.9 & 30.5 & 83.4 \\
10 & 3.55 & 1.89 & 2.71 & 64.9 & 35.0 & 99.9 \\
11 & 2.82 & 1.90 & 2.31 & 58.8 & 50.2 & 109.0 \\
12 & 2.20 & 1.28 & 1.65 & 50.1 & 43.3 & 93.4 \\
13 & 2.10 & 1.10 & 1.14 & 43.9 & 43.8 & 87.7 \\
\hline
\end{tabular}

' Including fruit $(0.64 \% \mathrm{~N})$. N content of fruit was $23.3 \mathrm{~g} / \mathrm{plant}$.

probably due to the movement of the nutrients from leaf and pseudostem to the fruit.

$\mathrm{Ca}$ and $\mathrm{Mg}$ levels indicated no clear superiority in favor of leaves or pseudostem (table 5 to 6). There was a trend for reduction in the percentage $\mathrm{Mg}$ content of the leaves with increasing age, and both leaves and pseudostem showed a definite drop in $\mathrm{Mg}$ level at the fruiting stage. No such trends were apparent for Ca.

In weight of nutrients, the total plant increased slowly up to the third month, somewhat more rapidly from the third to fifth month, and very rapidly from the sixth to eleventh month. After the eleventh month, there was a decrease in total nutrients which continued until harvest. The decrease in total nutrients was probably due to the movement of the $\mathrm{N}, \mathrm{P}, \mathrm{K}, \mathrm{Ca}, \mathrm{Mg}$ from leaf and pseudostem to the fruit.

The leaves had a higher nutrient uptake rate (weight basis) than the 
pseudostem in the early stages of growth for all nutrients studied except $K$. The change from higher nutrient weight in the pseudostem as compared to the leaves occurred for $\mathrm{P}$ and $\mathrm{Ca}$ at $11 \mathrm{mo}$ and for $\mathrm{Mg}$ at 7. Uptake of $\mathrm{N}$ was higher for leaves than pseudostem at all ages except 13 mo (table 2). Uptake of $\mathrm{K}$ was higher for pseudostem than for leaves except for the fourth and sixth months (table 4). The ratios of

TABLE 3.-Dry-weight $P$ content (percentage and weight) of components of a plantain plant at various stages of growth

\begin{tabular}{ccccccc}
\hline \multirow{2}{*}{$\begin{array}{c}\text { Age of } \\
\text { plant }\end{array}$} & \multicolumn{6}{c}{ P content } \\
\cline { 2 - 7 } Mo. & Leaves & Pseudostem & Whole plant & Leaves & Pseudostem & Whole plant \\
\hline Mo & $\%$ & $\%$ & $\%$ & $g$ & $g$ & $g$ \\
0 (corm) & - & - & 0.16 & - & - & 0.11 \\
1 & 0.30 & 0.28 & .29 & 0.02 & 0.02 & .04 \\
2 & .25 & .19 & .22 & .04 & .02 & .06 \\
3 & .25 & .19 & .22 & .12 & .07 & .19 \\
4 & .22 & .18 & .21 & .45 & .19 & .64 \\
5 & .21 & .17 & .20 & .50 & .26 & .84 \\
6 & .21 & .16 & .19 & 2.15 & .87 & 3.02 \\
7 & .20 & .15 & .18 & 1.91 & 1.46 & 3.37 \\
8 & .20 & .14 & .17 & 2.87 & 1.73 & 4.60 \\
9 & .21 & .14 & .17 & 3.36 & 2.46 & 5.82 \\
10 & .20 & .13 & .16 & 3.66 & 2.41 & 6.07 \\
11 & .18 & .16 & .17 & 3.75 & 4.23 & 7.98 \\
12 & .16 & .12 & .14 & 3.64 & 4.06 & 7.70 \\
13 & .10 & .06 & .081 & 2.09 & 2.39 & 4.48 \\
\hline
\end{tabular}

' Including fruit (.08\% $\mathrm{P}$; total $\mathrm{P}$ in fruit $2.91 \mathrm{~g})$

TABLE 4. -Dry-weight basis $K$ content (percentage and weight) of components of a plantain plant at various stages of growth

\begin{tabular}{ccccccc}
\hline \multirow{2}{*}{$\begin{array}{c}\text { Age of } \\
\text { plant }\end{array}$} & \multicolumn{6}{c}{ K content } \\
\cline { 2 - 7 } & Leaves & Pseudostem & Whole plant & Leaves & Pseudostem & Whole plant \\
\hline Mo & $\%$ & $\%$ & $\%$ & $g$ & $g$ & $g$ \\
0 (corm) & - & - & 5.56 & - & - & 4.0 \\
1 & 10.50 & 14.57 & 12.44 & 0.7 & 0.8 & 1.5 \\
2 & 7.89 & 16.58 & 11.67 & 1.2 & 2.0 & 3.2 \\
3 & 7.55 & 14.15 & 10.37 & 3.7 & 5.4 & 9.0 \\
4 & 7.36 & 14.10 & 9.64 & 14.9 & 14.6 & 29.5 \\
5 & 6.53 & 12.43 & 8.66 & 17.9 & 19.2 & 37.1 \\
6 & 5.67 & 9.35 & 6.95 & 58.0 & 50.9 & 108.9 \\
7 & 6.48 & 11.65 & 9.11 & 61.8 & 113.7 & 175.5 \\
8 & 7.43 & 12.00 & 9.54 & 106.6 & 148.0 & 254.6 \\
9 & 6.94 & 12.10 & 9.54 & 119.9 & 212.3 & 332.2 \\
10 & 6.75 & 12.72 & 9.75 & 123.5 & 235.6 & 359.1 \\
11 & 7.20 & 14.15 & 11.09 & 150.1 & 374.1 & 524.2 \\
12 & 6.62 & 10.00 & 8.64 & 150.7 & 338.5 & 489.2 \\
13 & 4.70 & 9.90 & $5.90^{1}$ & 98.3 & 394.0 & 491.4 \\
\hline
\end{tabular}

${ }^{1}$ Including fruit $(2.22 \% \mathrm{~K}, 80.8 \mathrm{~g} /$ plant $)$. 
COMPOSITION OF PLANTAINS DURING GROWTH AND FRUITING 183

TABLE 5. -Dry-weight Ca content (percentage and weight) of components of a plantain plant at various stages of growth

\begin{tabular}{|c|c|c|c|c|c|c|}
\hline \multirow{2}{*}{$\begin{array}{l}\text { Age of } \\
\text { plant }\end{array}$} & \multicolumn{6}{|c|}{ Ca Content } \\
\hline & Leaves & Pseudostem & Whole plant & Leaves & Pseudostem & Whole plant \\
\hline Mo & $\%$ & $\%$ & $\%$ & $g$ & $g$ & $g$ \\
\hline 0 (corm) & - & - & 0.12 & - & - & 0.09 \\
\hline 1 & 0.86 & 0.74 & .81 & 0.1 & 0.1 & .2 \\
\hline 2 & .96 & 1.23 & 1.07 & 1 & 2 & .3 \\
\hline 3 & .98 & .95 & .97 & .5 & .4 & .9 \\
\hline 4 & .70 & 1.15 & .85 & 1.4 & 1.2 & 2.6 \\
\hline 5 & .76 & .98 & .84 & 2.1 & 1.5 & 3.6 \\
\hline 6 & .74 & 1.00 & .83 & 7.6 & 5.4 & 13.0 \\
\hline 7 & .96 & .99 & .97 & 9.2 & 9.6 & 18.8 \\
\hline 8 & 1.16 & 1.04 & 1.10 & 16.7 & 12.8 & 29.5 \\
\hline 9 & 1.00 & .84 & .92 & 17.3 & 14.7 & 32.0 \\
\hline 10 & 1.13 & .88 & 1.00 & 20.7 & 16.3 & 37.0 \\
\hline 11 & 1.13 & 1.19 & 1.16 & 23.6 & 31.5 & 55.1 \\
\hline 12 & .98 & .78 & .86 & 22.3 & 26.4 & 48.7 \\
\hline 13 & 1.29 & 1.07 & $.72^{1}$ & 27.0 & 42.6 & 69.6 \\
\hline
\end{tabular}

${ }^{1}$ Including fruit $(.02 \% \mathrm{Ca})$

TABLE 6. -Dry-weight Mg content (percentage and weight) of components of a plantain plant at various stages of growth

\begin{tabular}{|c|c|c|c|c|c|c|}
\hline \multirow{2}{*}{$\begin{array}{l}\text { Age of } \\
\text { plant }\end{array}$} & \multicolumn{6}{|c|}{ Mg content } \\
\hline & Leaves & Pseudostem & Whole plant & Leaves & Pseudostem & Whole plant \\
\hline Mo & $\%$ & $\%$ & $\%$ & $g$ & $g$ & $g$ \\
\hline 0 (corm) & - & - & 0.23 & - & - & 0.16 \\
\hline 1 & 0.49 & 0.38 & .41 & 0.03 & 0.02 & .05 \\
\hline 2 & .38 & .45 & .41 & .06 & .05 & .11 \\
\hline 3 & .30 & .37 & .34 & .15 & .14 & .29 \\
\hline 4 & .48 & .36 & .44 & .97 & .37 & 1.34 \\
\hline 5 & .37 & .20 & .31 & 1.01 & .31 & 1.32 \\
\hline 6 & .35 & .43 & .38 & 3.58 & 2.34 & 5.92 \\
\hline 7 & .29 & .32 & .30 & 2.76 & 3.11 & 5.87 \\
\hline 8 & .34 & .43 & .38 & 4.88 & 5.30 & 10.18 \\
\hline 9 & .28 & .33 & .31 & 4.84 & 5.79 & 10.63 \\
\hline 10 & .32 & .40 & .36 & 5.85 & 7.41 & 13.26 \\
\hline 11 & .32 & .43 & .38 & 6.67 & 11.37 & 18.04 \\
\hline 12 & .28 & .26 & .27 & 6.37 & 8.80 & 15.17 \\
\hline 13 & .22 & .26 & $.19^{1}$ & 4.60 & 10.35 & 14.95 \\
\hline
\end{tabular}

${ }^{1}$ Including fruit (.10\% Mg, $3.64 \mathrm{~g} \mathrm{Mg} /$ plant).

leaves to pseudostem for nutrient uptake at harvest were $\mathrm{N}, 1: 1 ; \mathrm{P}$, $1: 1 ; \mathrm{K}, 1: 4 ; \mathrm{Ca}, 1: 2$; and $\mathrm{Mg}, 1: 2$.

TOTAL NUTRIENT UPTAKE PER UNIT AREA HARVESTED

The NPK content (dry weight basis) of the plantain plant, including fruit, amounted to $691 \mathrm{~g}$ at harvest. This is not an overly large amount 
by itself. However, when the high number of plants per unit area used in modern planting practices $(2,988 /$ ha or $1,210 /$ acre) is considered, it becomes clear that this plant removes large quantities of nutrients from the soil. In table 7 , the NPK content of the plantain at harvest and its fertilizer equivalent $\left(\mathrm{N}, \mathrm{P}_{2} \mathrm{O}_{5}, \mathrm{~K}_{2}\right)$ are given.

The fruit, when removed from the field, contained $70 \mathrm{~kg} \mathrm{~N}$, and 21 $\mathrm{kg} / \mathrm{ha} \mathrm{P}_{2} \mathrm{O}_{5}$. Fortunately, left behind in the leaves and pseudostem are large quantities of NPK, equivalent to $262 \mathrm{~kg} \mathrm{~N}, 30 \mathrm{~kg} \mathrm{P}_{2} \mathrm{O}_{5}$, and 1,765

TABLE 7. - Nutrient contents of one hectare of plantains at harvest' and its fertilizer equivalents

\begin{tabular}{lrrrr}
\hline Nutrient & Leaves & Pseudostem & Fruit & Whole plant \\
\hline & $K g$ & $K g$ & $K g$ & $K g$ \\
$\mathrm{~N}$ & 131 & 131 & 70 & 332 \\
$\mathrm{P}$ & 6 & 7 & 9 & 22 \\
$\mathrm{~K}$ & 294 & 1,177 & 242 & 1,713 \\
$\mathrm{Ca}$ & 81 & 127 & 2 & 210 \\
$\mathrm{Mg}$ & 14 & 31 & 11 & 56 \\
& & Fertilizer equivalent & & \\
$\mathrm{N}$ & 131 & 131 & 70 & 332 \\
$\mathrm{P}_{2} \mathrm{O}_{5}$ & 14 & 16 & 21 & 51 \\
$\mathrm{~K}_{2} \mathrm{O}$ & 353 & 1,412 & 290 & 2,055 \\
$\mathrm{CaCO}_{3}$ & 203 & 318 & 5 & 526 \\
$\mathrm{MgO}$ & 23 & 51 & 18 & 92 \\
\hline
\end{tabular}

' Based on a spacing of $1.83 \times 1.83 \mathrm{~m}$, giving 2988 plants/ha.

$\mathrm{kg} \mathrm{K} \mathrm{K}_{2} 0 /$ ha. Weir (7), in Jamaica, estimated that the nutrients returned to the soil from a ha of bananas was $404 \mathrm{~kg} \mathrm{~N}, 101 \mathrm{~kg} \mathrm{P}_{2} \mathrm{O}_{5}$, and 1,513 kg $\mathrm{K}_{2} \mathrm{O}$. Any cultural practice which will retain the plant residues in the field rather than removing them will be of economic benefit to the farmer because of the potential fertilizer equivalent that these plant residues represent.

Large quantities of the mineral nutrients $\mathrm{Ca}$ and $\mathrm{Mg}$, used in liming, were taken up by the entire plant. An amount of limestone $\left(\mathrm{CaCO}_{3}\right)$ equivalent to $526 \mathrm{~kg}$ was taken up by 1 ha of plantains (table 7), with $\mathrm{Mg}$ uptake being much less. Fortunately, the amounts of $\mathrm{Ca}$ and $\mathrm{Mg}$ in the fruit are small, so that very little is removed from the field as compared to the quantities left behind in the leaves and pseudostems.

The quantities of nutrients taken up by the plantain are not entirely inherent in the plant itself. The nutrients available in the soil, from natural sources or added as fertilizers, will influence the totals extracted by the plant. For example, plantains growing on a Vertisol ( $\mathrm{pH} 7.4)$ on the southern coast of Puerto Rico, under irrigation, showed leaf $\mathrm{Mg}$ values $66 \%$ higher than those on the acid Ultisol used in this study. 
However, available soil $\mathrm{Mg}$ values were $1,200 \mathrm{p} / \mathrm{m}$ as compared to 100 for the Ultisols.

Regardless of the available supply of nutrients, the plantain exhibits an extraordinary ability to accumulate $\mathrm{K}$. In this study it is by far the leading element in total uptake. Compared to $\mathrm{N}$, it has a ratio of about $5: 1$ for the whole plant, $3: 1$ for the fruit, $9: 1$ for the pseudostem, and $2: 1$ for the leaves. Fertilizer analyses with a $1: 2 \mathrm{~N}: \mathrm{K}_{2} \mathrm{O}$ ratio are used for plantains in Puerto Rico. Weir (6) cites the average $\mathrm{N}: \mathrm{K}_{2} \mathrm{O}$ relationship for banana fertilizer as 1:1.86 for 18 banana-growing countries in the world, with a range from 1:0.83 to 1:4.

\section{RESUMEN}

Se sembraron plátanos (Musa acuminata $\times$ M. balbisiana $\mathrm{AAB}$ ) de la variedad Maricongo en la arcilla Humatas (Typic Tropohumults) en la región húmeda montañosa de Puerto Rico. Los mismos recibieron $678 \mathrm{~kg} / \mathrm{ha}$ de abono de analisis 10-5-20 y se les tomaron muestras mensualmente de la planta entera desde la siembra hasta la cosecha. Se registró una producción pequeña de materia seca durante los primeros 5 meses de crecimiento. De ahí en adelante, el crecimiento fue tal que se produjo materia seca abundante. Esta fluctuó entre 5 y $6 \%$ para los primeros 10 meses y luego aumentó a 9\% cuando se cosechó a los 13 meses. La fruta tenía un porcentaje medio de 32.6 de materia seca. Las hojas tuvieron un porcentaje de materia seca más alto que el pseudotallo hasta los 6 meses. De los 7 a los 10 meses, los pesos fueron similares. Después, el de los pseudotallos fue mayor. Con respecto del porcentaje de materia seca, el de las hojas fue 3 veces el del pseudotallo.

Los porcentajes de $\mathrm{N}$ y $\mathrm{P}$ fueron más altos en las hojas que en el pseudotallo en todas las etapas de crecimiento; lo contrario ocurrió con el K. El contenido de NPK tendió a disminuir con la edad de la planta. Las hojas absorbieron $\mathrm{N}$ y P a un ritmo mayer que el pseudotallo en las etapas iniciales de desarrollo. Los niveles de Ca y $\mathrm{Mg}$ no señalaron diferencias en contenido entre las hojas y el pseudotallo. Se registró una tendencia a disminuir el contenido en $\mathrm{Mg}$ en la hoja con mayor edad de la planta. El contenido de Mg de las hojas y el pseudotallo disminuyó mucho en la etapa de fructificación. La razón geométrica de absorción de nutrimentos, de hojas a tallos, cuando se cosechó fue como sigue: $\mathrm{N}, 1: 1, \mathrm{P}, 1: 1, \mathrm{~K}, 1: 4, \mathrm{Ca}, 1: 2, \mathrm{y} \mathrm{Mg}, 1: 2$.

A base de 2,988 plataneros por héctárea, el fruto usa $70 \mathrm{~kg}$ de $\mathrm{N}, 9 \mathrm{~kg} \mathrm{P}, 242$ de $\mathrm{K}, 2$ de Ca y 11 de $\mathrm{Mg}$. El pseudotallo y las hojas revierten al suelo $262 \mathrm{~kg}$ de $\mathrm{N}, 13$ de P y 1,471 de $\mathrm{K}, 208 \mathrm{~kg}$ de $\mathrm{Ca}, 45 \mathrm{~kg}$ de $\mathrm{Mg}$.

\section{LITERATURE CITED}

1. Caro-Costas, R., 1968. Effect of plant population and distribution on yields of plantains, J. Agric. Univ. P.R. 52: 256-9.

2. - Abruña, F., and Vicente-Chandler, J., 1964. Response to fertilization of strip cultivated plantains growing on a steep latosol in the humid mountain region of Puerto Rico, J. Agric. Univ. P.R. 48: 312-17.

3. Samuels, G., 1969. Foliar Diagnosis for Sugarcane. P.R. Agric. Res. Assoc. 362 pp.

4. Sánchez Nieva, F., Hernández, I., Guadalupe, R., and Bueso, C., 1971. Effect of time of planting on yields and processing characteristics of plantains, J. Agric. Univ. P.R. 55: 394-404.

5. Simmonds, N. W. 1966. Bananas., Longmans, London, 466 pp.

6. Walmsley, D., 1974. Mineral nutrition of two plantain (Musa, AAB Group) cultivars of the French and horn type. Proc. Caribb. Food Crops Soc., 12th Ann. Meet. Jamaica, 141-7.

7. Weir, C. C., 1974. Application of fertilizers to bananas in Jamaica, Res. and Dev. Dep. Banana Board Jam. Ann. Rep. pp. 111-14. 